\title{
Participación social en salud: campo fértil para la intervención de la terapia ocupacional
}

Riveros E. Maria Elena.

\begin{abstract}
- Resumen
Históricamente el quehacer de la Terapia Ocupacional ha puesto el acento en la intervención individual de las personas, mas que en el abordaje colectivo de los problemas de salud. Sin embargo, los tiempos han cambiado y cada vez con mayor fuerza se hace evidente la necesidad de incorporar modelos participativos que permitan obtener mayores y mas eficientes logros en relación a los problemas de salud que enfrentan personas, familias y comunidades. Al respecto, la Terapia Ocupacional enfrenta un gran desafío: incorporar esta "mirada participativa? en su quehacer y hacer de la participación una potente herramienta al servicio de la salud y calidad de vida de las personas. El presente trabajo hace un breve recorrido por el concepto de participación, las ventajas de usar modelos participativos, las principales resistencias y dificultades que enfrenta y como se ha dado su desarrollo histórico en el ambito de la salud. Termina identificando una serie de desafíos aun pendientes, circunscribiendo estos al quehacer de la Terapia Ocupacional.
\end{abstract}

\begin{abstract}
Occupational Therapy has traditionally concentrated on individual health interventions, instead of using a public health approach to Occupational Therapy health problems. Peoples, families and community needs have changed overtime, therefore Occupational Therapy actions must readjust itself to these changes and incorporate community participation models to enhance the efflciency and scope of its a interventions. This paper concentrates in the advantages of introducing community participation models to Occupational Therapy actions, and the main obstacles for changing the traditional approaches. The paper also concentrates on the challenges Occupational Therapy has in this field of public health action.
\end{abstract}

Escuela de Terapia Ocupacional. Facultad de Medicina. Universidad de Chile Contacto > > mriveros@machi.med.uchile.cl 